Rutgers Journal of Law \& Urban Policy, vol. 2, núm. 1, 2005, pp. 196-2003.

\title{
Basic income as a socialist project.
}

\section{Wright, Erik Olin.}

Cita:

Wright, Erik Olin (2005). Basic income as a socialist project. Rutgers Journal of Law \& Urban Policy, 2 (1), 196-2003.

Dirección estable: https://www.aacademica.org/erik.olin.wright/23 ARK: https://n2t.net/ark:/13683/paqp/wZ9 


\title{
BASIC INCOME AS A SOCIALIST PROJECT1
}

\author{
Erik Olin Wright ${ }^{2}$
}

Most discussions of basic income revolve around two clusters of issues: first, the normative implications of basic income for various conceptions of justice, and second, the pragmatic problems of the sustainability of basic income given a range of economic considerations including such things as effects on tax rates, incentives, labor markets, and so on. These are obviously important issues, but I want to explore a different sort of question: In what ways can a guaranteed basic income be considered part of a broad socialist challenge to capitalism?

This may seem to some people a somewhat irrelevant question, perhaps even a stupid question, since the very idea of socialism has lost so much of its intellectual and political appeal in recent years. The idea that there is a feasible systemic alternative to capitalism, either in the sense of a workable design for alternative economic institutions, or in the sense of a politically achievable goal, seems far-fetched to many people, even those who still share the traditional socialist criticisms of capitalism.

I feel that it is still meaningful to talk about a socialist challenge to capitalism even in the absence of a clear, well-articulated model of the design of socialist institutions. What we can try to do is articulate a set of anti-capitalist socialist principles and use these to indicate movements away from capitalism in a socialist direction even if we lack a clear understanding of our destination. It is like going on a journey with a compass that tells us the direction we are moving, but without a road map which lays out the entire route from the point of departure to the final destination. Of course, this approach is perilous: we may encounter chasms which we cannot cross or unforeseen obstacles which force us to move in a direction we had not planned. But it may also be the case that if we want to leave the social world in which we currently live, we have no better device than principles of direction rather than known-in-advance destinations.

This way of thinking about socialism rejects the simple dichotomous view of capitalism vs. socialism. It implies that capitalist societies differ in how "socialistic" they are - to use an old right wing expression - and that, with respect to the values and emancipatory aspirations of socialists, it is better to be in a capitalist society with strong socialist elements than in a capitalist society without those elements. This

\footnotetext{
${ }^{1}$ Professor Wright's paper is being published simultaneously in Basic Income Studies, Vol. 1, No. 1 (2005).

${ }^{2}$ Erik Olin Wright is a Sociology professor at the University of Wisconsin - Madison.
} 
leaves open the questions of how far these principles can be pushed, the extent to which capitalism limits the acceptable range of these principles, and whether or not at some point a sharper rupture with capitalist institutions will be necessary for further advance. I do not know if a long sequence of socialist moves within the institutional spaces allowed in capitalism could cumulatively lead to a metamorphosis of capitalism itself, or whether in the end such a process will reach untransgressable limits. I don't know how to answer such questions and I suspect that they are not really answerable. In the absence of a compelling answer, then, the best we can do is chart the principles that yield a direction of progressive change without a clear destination.

But before discussing these principles we need to briefly review the core ideas of the socialist critique of capitalism, for it is against this backdrop that the project of a socialist alternative can be formed. This will be followed by an elaboration of three principles defining the direction of a socialist journey, and then a discussion of the ways in which basic income might contribute to this movement.

\section{THE CORE SOCIALIST CRITIQUE OF CAPITALISM}

At the core of the traditional socialist critique of capitalism are six main claims:

1. Capitalist class relations perpetuate eliminable forms of human suffering. While capitalism is an engine of economic growth, it also inherently generates marginalization, poverty, deprivation, and what is perhaps even worse, obstructs the elimination of these forms of human suffering. In principle, of course, the fruits of growth could be distributed in ways that improve everyone's material welfare, a point continually made by defenders of capitalism under the slogan "a rising tide lifts all boats." However, there is no mechanism internal to capitalism to generate the redistribution needed to produce these effects. The harshest anti-capitalist rhetoric denouncing capitalism in terms of oppression and exploitation centers on these issues.

2. Capitalism blocks the universalization of conditions for human flourishing. Even apart from abject poverty and material deprivations, the inequalities of material conditions of life combined with the strong competitive pressures of capitalism generate pervasive, unnecessary deficits in human flourishing (understood as the realization of human potentials) for a large segment of the population. These deficits in human flourishing are especially sharp when capitalist competition takes the form of "winner-take-all" markets that result in inequalities in outcomes vastly disproportionate to inequalities of effort and "merit." The high levels of productivity and wealth generated by capitalism opens up the prospect for a universilization of the conditions for human flourishing, but the 
inequalities also generated by capitalism block the realization of that potential. 3

3. Capitalism perpetuates eliminable deficits in individual freedom and autonomy. If there is one value that capitalism claims to achieve to the highest possible extent it is individual freedom and autonomy. "Freedom to choose," rooted in strong individual property rights is, as Milton Friedman has argued, the central moral virtue claimed by defenders of capitalism. There are two principal reasons, however, why capitalism inherently fails to live up to this ideal: First, the relations of domination within capitalist workplaces constitute pervasive restrictions on individual autonomy and self-direction. The apparent freedom of individuals to quit their jobs provides only an illusory escape from such domination, since without ownership of the means of production, workers must seek work in capitalist firms or state organizations. Second, the large inequalities of wealth which capitalism generates constitute, as Philippe van Parijs has argued, a significant inequality in "real freedom," since it implies that some people have a much greater capacity to act on their life plans than others. While it is certainly true that relative to previous forms of society capitalism enhances individual autonomy and freedom, it also erects barriers to the full realization of this value.

4. Capitalism violates liberal egalitarian principles of social justice. The private accumulation of wealth gives some people inherent, unfair advantages over others. Particularly with respect to children this violates principles of equality of opportunity. But even beyond issues of intergenerational transmission of advantages, since the private profitmaximizing logic of capitalism means that capitalist firms have an inherent tendency to try to displace costs on others, capitalism imposes unchosen burdens on many people in the form of negative externalities. Negative externalities are not simply a problem of inefficiency - although they are that as well - but of injustice. This injustice of negative externalities is especially sharp when it is conceived of intergenerationally - the ways in which social production today imposes unchosen costs on future generations. This of course would be an inherent problem in any social organization of production, since future generations cannot participate in weighing long term trade-offs. But because of the ways in which capitalism promotes narrow self-interest and shortens time horizons, such problems of intergenerational negative externalities are intensified.

5. Capitalism under-produces public goods. For well-understood reasons, acknowledged by defenders of capitalism as well as its critics, capitalism inherently generates significant deficits in the production of public goods and in this respect it is inefficient (i.e. the lack of adequate public goods is efficiency reducing).

3 The claim that capitalism systematically generates a gap between the potential for human flourishing and the realization of human flourishing is similar to G.A Cohen's critique of capitalism in terms of fettering the rational use of the forces of production 
6. Capitalism limits democracy. There are three principle mechanisms at work here. First, by definition, "private" ownership of means of production means that significant domains of decisions that have broad collective effects are simply removed from collective decisionmaking. While the boundaries between private property rights and those subjected to public control are periodically contested, the fact of the matter is that in capitalist society the presumption is that decisions over property are private matters and only in special circumstances can public bodies legitimately encroach upon them. Second, the high concentrations of wealth and economic power generated by capitalist dynamics subvert principles of democratic political equality. People with money have a disproportionate influence on political outcomes through a variety of mechanisms: the ability to contribute to political campaigns, influence on the media, the capacity to lobby political officials, and so on. Third, the inability of democratic bodies to control the movement of capital undermines the ability of democracy to set collective priorities over the use of social resources, especially the social surplus.

These six propositions define what is wrong with capitalism from a radical egalitarian, democratic normative standpoint. If it could be shown that these propositions are false in the sense that capitalism, if left to its own devices, would in time significantly remedy all of these harms, then the impulse to articulate the parameters of a socialist alternative to capitalism would be significantly undercut. But given our current state of knowledge about the inherent dynamics of capitalism, this seems quite implausible. The question then becomes, what are the principles of deliberate institutional transformation towards a progressive, egalitarian, democratic alternative? How should we specify the principles of the socialist compass?

\section{THREE PRINCIPLES OF A SOCIALIST CHALLENGE TO CAPITALISM}

There are many possible principles defining the socialist compass.

Here I will focus on three:

1. Strengthening the power of labor relative to capital. This is one of the central traditional themes of socialist thought, especially in its Marxist incarnation: socialism is a system of production within which the working class is the dominant class; capitalism is a system within which the capitalist class is the dominant class. Within capitalism, then, social changes which strengthen the power of labor can be thought of as moving in the direction of socialism even if this does not immediately threaten the dominance of capital as such.

2. Decommodifying labor power. This is also a familiar theme in discussions of socialism. One of the hallmarks of capitalism is that people who do not own means of production must sell their labor power on a labor market to an employer in order to acquire their means of 
subsistence. This is sometimes referred to as the commodification of labor (or perhaps, more precisely, of labor power) since people's capacity to work is being treated as if it were a commodity. To the extent that workers are able to have their needs met outside of the labor market through some process of social provision, their labor power is decommodified. Commodification is thus a variable and one can speak of the degree of commodification and decommodification of labor power. If socialism is an economy directly oriented to the satisfaction of needs rather than the maximization of profit, then such decommodification of labor power can be thought of as a movement in the direction of socialism.

3. Strengthening the power of civil society to shape the priorities for the use of the social surplus and the organization of economic activity. This third point is less familiar, and perhaps more controversial. It implies a contrast between what I would call statism and social-ism. Both are forms of non-capitalist economic organization. In statism, state power plays the primary role in allocating the social surplus to alternative priorities and directing process of production. The clearest examples were the highly centralized bureaucratic systems of command-economy in places like the Soviet Union. In contrast, in socialism what might be loosely termed "social power" plays this role. "Social power" comes from the capacity to mobilize people for cooperative, voluntary collective actions of various sorts in civil society. It is contrasted to economic power, based on the ownership and control of economic resources, and state power, based on the control of rule making and rule enforcing capacity over territory. The idea of democracy, in these terms, can be thought of as a specific way of linking social power and state power: in the ideal, state power is fully subordinated to social power; in practice, social power operates as a significant constraining force on state power. Democracy is thus, inherently, a deeply socialist principle.

The idea of a socialism rooted in social power is a much less clear idea than statism, and indeed many people use the term "socialism" to describe what I am here calling socialism. It involves two crucial notions. First, the idea that social power shapes economic activity means that at the macro-level investment priorities are set through a process of vigorous public-participatory democratic deliberation rather than through either the exercise of private economic power in the market or the exercise of authoritative bureaucratic command through the state. This is sometimes referred to as "economic democracy." Second, at the more micro-level, collective associations in civil society are directly engaged in economic activity to satisfy needs. Such needs-oriented production is not organized through markets or by state bureaucracies, but through the selforganization of collective actors in society. This corresponds to what, in some discussions, is referred to as the "social economy." This would include things like childcare, eldercare and home healthcare services, recreational services, and a wide array of cultural and arts activities. But it might also be expanded to a much wider inventory of economic activities including aspects of material production as well. The production of these 
services in the social economy, it must be emphasized, is social, not private: the issue here is not moving childcare or eldercare services from the market or state provision back to the family. Rather, the social economy is built around the public provision of such services by collective association rather than by the state or market. Socialism, them, combines democratic deliberation over broad investment allocations with selforganized voluntary associational organization of economic activity. As in the other two principles, the strength of social power over the economy is a variable and thus we can speak of moving in a socialist direction when such power increases.

\section{BASIC INCOME AND SOCIALISM}

If we accept these three principles - strengthening the power of labor relative to capital, decommodifying labor power, and strengthening social power over economic activity - as criteria for movement from capitalism towards socialism, the next questions is how different proposals for institutional reforms within capitalism might contribute to one or another of these principles. Pension fund reform, which gave unions the potential to exert control over the exercise of corporate power, as argued by William Greider, for example, could be viewed as contributing in some way to the third criterion. What about basic income? I will argue that basic income can be viewed as a socialist reform on all three of these criteria. Of course, the extent to which basic income contributes to a socialist project depends significantly upon the level of a basic income, and it depends upon on the sustainability of basic income on narrow economic grounds for all the familiar reasons explored in debates over basic income. For the present purposes I will make two assumptions: First, that an unconditional basic income is set at a level that would enable a person to live at a respectable, no frills level. That is, the level of the grant is sufficiently high that withdrawing from the capitalist labor market is a meaningful option. Second, I will assume that a grant at this level does not generate incentive problems, either for workers or investors, of the sort that would render the grant unsustainable over time. On these assumptions, then, basic income would contribute to each of the three principles of a socialist project.

1. Basic Income and the balance of class power. A generous basic income has the potential to contribute, in the long run, to strengthening the power of labor vis-à-vis capital for three reasons. First, to the extent that labor markets become tighter in a capitalist economy with a basic income, the bargaining position of individual workers will increase. Second, generally speaking labor is collectively in a better bargaining position when labor markets are tight. And third, basic income is a kind of unconditional and inexhaustible strike fund, which also would contribute to strengthening the labor movement. Even if basic income was not accompanied by more favorable laws governing the process of union organization, therefore, it would in this way enhance the capacity of workers to struggle for unions. Now union supporters have, in some times 
and places, argued against basic income for a variety of reasons.

Sometimes unionists object to basic income on the same grounds that unions are sometimes hostile to welfare: this is just a device by which hardworking people are forced to support the lazy. But there is also an argument more directly linked to union power: the fear is that with a basic income workers would no longer need unions. If the only function of unions were to guarantee minimum standards of living, then this might be a realistic concern. But insofar as unions are also concerned with the organization of the labor process, conditions of work, fair treatment within disputes, technology, and so on, basic income would in no way threaten the function of unions. In any case, the added capacity for struggle provided by the guaranteed income seems likely to be a bigger effect than any marginal reduction in functions for collective organization. Thus basic income is likely to shift class power in ways favorable to workers.

2. Decommodifying labor. The most obvious effect of basic income is on the partial decommodification of labor. This is the aspect of basic income that has received the most attention. It is embodied in Philippe van Parijs's clarion call "Real Freedom for All." If a sustainable basic income provides for a culturally acceptable level of subsistence, then this means that the basic needs of people are met without the compulsion to enter the labor market.

3. Enlarging the potential for a social economy. Basic income may not, at first glance, seem to have much to do with the socialist principle of enhancing social power over economic activity. After all, basic income is an individually targeted transfer, and no constraints are placed on what the individual does with this grant. In such terms it seems like a purely individualistic reform. I think this is a very limited way of understanding the implications of basic income. We have already seen one way in which basic income may have collective consequences through the ways in which it may enhance the balance of power between labor and capital. Basic income also, I would argue, has the potential of creating the conditions for a greatly expanded and deepened social economy. The social economy is an alternative way of organizing economic activity that is distinct both from capitalist market provision and state provision. Its hallmark is production organized by collectivities directly to satisfy needs not subject to the discipline of profit-maximization or state-technocratic rationality. A significant segment of such activity involves the provision of various kinds of services, many of which are quite labor intensive. If anything, such services are likely to grow in importance in the future. One of the main problems that collective actors face in the social economy is generating a decent standard of living for the providers of these services. This is, of course, a chronic problem in the arts, but it also affects efforts by communities to organize effective social economy services for various kinds of care giving activities. Basic income substantially solves this problem. Basic income can be viewed as potentially a massive transfer of social surplus from the capitalist market sector to the social economy, from capital accumulation to what might be termed social accumulation - the 
accumulation of the capacity of society for self-organization of needsoriented economic activity.

By itself, of course, basic income only contributes to solving one of the problems facing an empowered social economy - the breaking of the link between a basic standard of living and participation in the capitalist labor market. It does not provide capital grants for infrastructure and nonlabor inputs for the social economy. As such, the enrichment of social economy production by basic income is likely to be limited to labor intensive services. But it is also the case that basic income provides a subsidy for political activity, community organizing and social movements, since these too depend, above all, on the time and energy of people. And this, in turn, may enhance the prospects for a broader array of reforms that eventually enlarge the space for movement in the direction of socialism.

\section{CONCLUSION}

All of this may seem like wishful thinking. Socialism in any sense of the word seems so far off the agenda in the American political context of today. And, of course, if I am right that a generous basic income would contribute in a meaningful way to revitalizing a socialist challenge to capitalism by partially decommodifying labor, empowering workers and enlarging the non-market social economy, then this may imply that basic income is even more off the agenda than we may have thought for such efforts are likely to trigger more concerted opposition from the capitalist class. Still, we will not live under the cloud of right wing capitalist triumphalism forever. There will be renewed episodes of progressive, egalitarian politics even in America. And when such episodes occur, basic income should be high on the agenda not simply because of the ways it directly deals with a range of fundamental issues of social justice, but because of the ways it may contribute to a broader transformation of capitalism itself. 